\title{
Corrigendum: Fire Responses to the 2010 and 2015/2016 Amazonian Droughts
}

\author{
Celso H. L. Silva Junior ${ }^{1,2 *}$, Liana O. Anderson ${ }^{1,3}$, Alindomar L. Silva ${ }^{2}$, \\ Catherine T. Almeida ${ }^{1,2}$, Ricardo Dalagnol ${ }^{1,2}$, Mikhaela A. J. S. Pletsch $^{2}$, Thales V. Penha ${ }^{2}$, \\ Rennan A. Paloschi ${ }^{2}$ and Luiz E. O. C. Aragão ${ }^{1,2,4}$ \\ ${ }^{1}$ Tropical Ecosystems and Environmental Sciences Laboratory, São José dos Campos, Brazil, ${ }^{2}$ National Institute for Space \\ Research, São José dos Campos, Brazil, ${ }^{3}$ National Center for Monitoring and Early Warning of Natural Disasters, São José \\ dos Campos, Brazil, ${ }^{4}$ College of Life and Environmental Sciences, University of Exeter, Exeter, United Kingdom
}

Keywords: old-growth forest, temperature, rainfall, remote sensing, CHIRPS, MODIS, GFEDv4

\section{OPEN ACCESS}

Edited and reviewed by: Juan Carlos Jimenez,

University of Valencia, Spain

*Correspondence:

Celso H. L. Silva Junior

celso.junior@inpe.br

Specialty section:

This article was submitted to Interdisciplinary Climate Studies,

a section of the journal

Frontiers in Earth Science

Received: 31 May 2019 Accepted: 05 June 2019

Published: 19 June 2019

Citation:

Silva Junior CHL, Anderson LO, Silva AL, Almeida CT, Dalagnol R, Pletsch MAJS, Penha TV, Paloschi RA and Aragão LEOC (2019)

Corrigendum: Fire Responses to the 2010 and 2015/2016 Amazonian Droughts. Front. Earth Sci. 7:160. doi: 10.3389/feart.2019.00160

\section{A Corrigendum on}

Fire Responses to the 2010 and 2015/2016 Amazonian Droughts

by Silva Junior, C. H. L., Anderson, L. O., Silva, A. L., Almeida, C. T., Dalagnol, R., Pletsch, M. A. J. S., et al. (2019). Front. Earth Sci. 7:97. doi: 10.3389/feart.2019.00097

In the original article, there were two typos in the Abstract. In the following sentence: "The two analyzed droughts emitted together $0.47 \mathrm{Pg} \mathrm{CO}_{2}$, with $0.23 \mathrm{Pg} \mathrm{CO}_{2}$ in 2010, $0.15 \mathrm{Tg} \mathrm{CO}$ in 2015 and $0.09 \mathrm{Tg} \mathrm{CO}_{2}$ in 2016, which represented, respectively, 209\%, 136\%, 82\% of annual Brazil's national target for reducing carbon emissions from deforestation by 2017 (approximately $0.11 \mathrm{Pg}$ $\mathrm{CO}_{2}$ year $^{-1}$ from 2006 to 2017).", the correct unit of measurement is "Pg" and not "Tg" as written in the published version.

A correction has been made to Abstract:

The two analyzed droughts emitted together $0.47 \mathrm{Pg} \mathrm{CO}_{2}$, with $0.23 \mathrm{Pg} \mathrm{CO}_{2}$ in 2010, $0.15 \mathrm{Pg}$ $\mathrm{CO}_{2}$ in 2015 and $0.09 \mathrm{Pg} \mathrm{CO}_{2}$ in 2016, which represented, respectively, 209\%, 136\%, 82\% of annual Brazil's national target for reducing carbon emissions from deforestation by 2017 (approximately $0.11 \mathrm{Pg} \mathrm{CO}_{2}$ year $^{-1}$ from 2006 to 2017).

The authors apologize for this error and state that this does not change the scientific conclusions of the article in any way. The original article has been updated.

Copyright (๑) 2019 Silva Junior, Anderson, Silva, Almeida, Dalagnol, Pletsch, Penha, Paloschi and Aragão. This is an open-access article distributed under the terms of the Creative Commons Attribution License (CC BY). The use, distribution or reproduction in other forums is permitted, provided the original author(s) and the copyright owner(s) are credited and that the original publication in this journal is cited, in accordance with accepted academic practice. No use, distribution or reproduction is permitted which does not comply with these terms. 